\title{
APLIKASI METODE FOAM-MAT DRYING DALAM PEMBUATAN BUBUK SUSU KEDELAI INSTAN
}

Application of Foam-Mat Drying Method in Processing of Instant Soybean Milk Powder

\author{
Dian Purbasari ${ }^{1) *}$ \\ ${ }^{1)}$ Jurusan Teknik Pertanian, Fakultas Teknologi Pertanian, Universitas Jember \\ Jalan Kalimantan No. 37 Kampus Bumi Tegal Boto, Jember, Jawa Timur \\ *Korespondensi Penulis: dianpurbasari@unej.ac.id
}

\begin{abstract}
As one of the products from soybean, soybean milk is widely known and appreciated by the public because of its benefits for health. Problems are often encountered in the processing of liquid soybean milk, such as short shelf life of it and easy to loss of quality. One alternative treatment that can extend the shelf life is to turn it into an instant soybean milk powder by drying method. Making instant soybean milk powder in this study used a foam-mat drying method. The purpose of this research was to study the application of foam-mat drying method on the characteristic (quality) of instan soybean milk powder produced. The results showed that the best treatment according to the drying time parameters was at 10\% dextrin and 1\% Tween 80. Physical characteristics of instant soybean milk powder had the highest yield values (16.10\%) at a drying temperature of $60^{\circ} \mathrm{C}$, the value of lightness $(L)$ about 84.2; value of redness $(a)$ about 1.3; yellowish value $(b)$ about 24, and water absorption (DSA) of $1.68 \mathrm{~mL} / \mathrm{g}$. Chemical analysis resulted that water content of $3.05 \%$ at the drying temperature of $70^{\circ} \mathrm{C}$, while the highest protein content at the drying temperature of $60^{\circ} \mathrm{C}$ amounted to $17.34 \%$ and the highest fat content about $11.36 \%$ at drying temperature of $50^{\circ} \mathrm{C}$.
\end{abstract}

Keywords: foam-mat drying, instant, shelf life, soybean milk

\section{PENDAHULUAN}

Susu kedelai memiliki dua macam bentuk yaitu cair dan bubuk. Kelemahan susu kedelai cair adalah tidak tahan lama sehingga gizi dan cita rasa berubah. Susu kedelai cair menjadi media pertumbuhan bakteri yang sempurna karena mengandung banyak gizi sehingga menjadi cepat basi. Salah satu pengolahan yang dapat memperpanjang daya simpan adalah merubahnya menjadi susu kedelai bubuk melalui pengeringan. Pengeringan dilakukan untuk menghasilkan produk yang dapat disimpan lebih lama, mempertahankan daya fisiologis bahan yang dikeringkan, mendapatkan kualitas yang lebih baik dan menghemat biaya pengangkutan. Menurut Winarno (2007), bentuk bubuk memiliki kelebihan yaitu lebih awet, ringan dan volumenya lebih kecil sehingga dapat mempermudah dalam pengemasan dan pengangkutan.
Pembuatan bubuk susu kedelai
instan dalam industri umumnya
menggunakan metode spray drying Namun produk yang dihasilkan harganya mahal karena tingginya biaya yang harus dikeluarkan untuk memenuhi alat pengering spray drying, sehingga dalam skala kecil kurang efisien. Oleh karena itu, perlu dicari alternatif lain yang lebih murah dan hasilnya sama baiknya dengan hasil pengeringan menggunakan spray drying. Metode foam mat drying menjadi salah satu alternatif yang bisa digunakan dan dikembangkan pada industri kecil dan menengah di Indonesia.

Teknik foam mat drying adalah suatu proses pengeringan dengan pembuatan busa dari bahan cair yang ditambah dengan foam stabilizer dengan pengeringan pada suhu $70-75^{\circ} \mathrm{C}$, kemudian dituangkan di atas loyang atau wadah. Selanjutnya, dikeringkan dengan 
oven blower atau tunnel dryer sampai larutan kering dan proses berikutnya adalah penepungan untuk menghancurkan lembaran-lembaran kering (Khotimah, 2006). Dalam pengolahan bubuk susu kedelai instan diperlukan adanya bahan pengisi (filler) dan bahan pembusa (foaming agent). Bahan pengisi yang digunakan adalah dekstrin dan Tween 80 sebagai bahan pembusa. Dekstrin memiliki sifat-sifat antara lain mengalami proses dispersi yang cepat, memiliki daya larut yang tinggi, mampu membentuk film, memiliki sifat higroskopis yang rendah, mampu membentuk body, sifat browning rendah, mampu menghambat kristalisasi dan memiliki daya ikat yang kuat (Hui, 1992). Tween 80 berfungsi untuk memperbanyak terbentuknya busa serta menurunkan tegangan permukaan antara dua fasa (Prasetyo dan Vincentius, 2005). Busa yang terbentuk tersebar sebagai lembaran tipis dan terkena aliran udara panas sampai dikeringkan ke tingkat kelembaban yang dibutuhkan (Rajkumar, 2007).

Dalam pengolahan bubuk susu kedelai dibutuhkan adanya bahan pengisi (filler) dan bahan pembusa (foaming agent). Bahan pengisi yang digunakan yaitu maltodekstrin. Sifat-sifat yang dimiliki maltodekstrin antara lain mengalami proses dispersi yang cepat, memiliki daya larut yang tinggi, mampu membentuk film, memiliki sifat higroskopis yang rendah, mampu membentuk body, sifat browning rendah, mampu menghambat kristalisasi dan memiliki daya ikat yang kuat (Hui, 1992). Dalam penelitian ini bahan pengisi yang digunakan adalah dekstrin dan bahan pembusa yaitu Tween 80. Tujuan penelitian ini adalah untuk mempelajari aplikasi metode foam-mat drying terhadap karakteristik (kualitas) bubuk susu kedelai yang dihasilkan. Selain itu juga memberikan informasi kondisi operasi metode foam-mat drying terbaik pada bubuk susu kedelai instan sesuai standar SNI.

\section{METODE PENELITIAN}

\section{Alat dan Bahan}

Alat-alat yang digunakan untuk membuat bubuk susu kedelai instan antara lain timbangan digital, sendok, baskom, panci, termometer, wadah plastik, kain saring, kompor, blender, mixer, loyang, pengering oven, ayakan 80 mesh, dan plastik klip. Alat yang digunakan untuk analisis antara lain timbangan analitik, beaker glass, gelas ukur, erlemeyer, pipet ukur, pipet tetes, spatula, cawan petri, desikator, kertas saring, oven, labu kjeldahl, dekstruktor dan sentrifuse.

Bahan utama yang digunakan dalam penelitian ini adalah kacang kedelai. Bahan pengisi yang digunakan adalah dekstrin dan bahan pembusa Tween 80 . Bahan kimia yang digunakan untuk analisis antara lain aquades, tablet kjeldahl, larutan $\mathrm{H}_{2} \mathrm{SO}_{4}$ pekat, indikator $\mathrm{PP}$, larutan asam borat 3\%, indikator metal merah, larutan $\mathrm{NaOH} 32 \%$, larutan $\mathrm{HCl}$ $0,1 \mathrm{~N}$ dan petroleum eter.

\section{Tahapan Penelitian}

\section{Pembuatan Susu Kedelai Bubuk Instan}

Pembuatan susu kedelai mengacu pada metode Pramitasari (2010) yang telah dimodifikasi Pradana et al. (2014). Pembuatan bubuk susu kedelai instan berdasarkan metode modifikasi Pratiwi dan Suharto (2015) dilakukan dengan memvariasi konsentrasi bahan pembusa (Tween 80;0,5\% dan 1\%) dan bahan pengisi (dekstrin; $5 \%$ dan $10 \%$ ) dan variasi suhu pengeringan $\left(50^{\circ} \mathrm{C}, 60^{\circ} \mathrm{C}\right.$ dan $\left.70^{\circ} \mathrm{C}\right)$. Susu kedelai cair yang diperoleh pada tahap pertama dicampur dengan bahan pembusa Tween $80(0,5 \%, 1 \%$, v/v) dan dihomogenisasi menggunakan mixer selama 3 menit dan kemudian ditambahkan dengan bahan pengisi dekstrin (5\% dan 10\%, b/v) kemudian diaduk menggunakan mixer selama 5 
menit. Susu kedelai selanjutnya dituang pada loyang stainless steel dengan ketebalan $2 \mathrm{~mm}$. Loyang yang berisi susu kedelai dimasukkan oven dan dikeringkan pada variasi temperatur yang diinginkan sampai beratnya konstan.

\section{Metode Analisis}

Analisis kualitas produk meliputi analisis fisik yaitu rendemen (Yuwono dan Susanto, 2001), daya serap air (Traina dan Breene, 1994) dan warna. Analisis kimia yang dilakukan yaitu kadar air (AOAC 1995), kadar protein (AOAC 1995 ) dan kadar lemak (AOAC 1995).

\section{Analisis Rendemen (Yuwono dan Susanto, 2001)}

Rendemen produk hidrolisat merupakan hasil akhir yang dihitung berdasarkan proses input dan output. Berikut rumus yang digunakan:

$$
\text { Rendemen }(\%)=\frac{\mathrm{A}}{\mathrm{B}} \times 100 \%
$$

Keterangan:

$\mathrm{A}=$ berat hidrolisat setelah dikeringkan $(\mathrm{g})$

$\mathrm{B}=$ berat basah sampel awal setelah perendaman $(\mathrm{g})$

Daya Serap Air (Traina dan Breene, 1994)

Pengukuran daya serap air dilakukan dengan menggunakan metode sentrifuse. Sampel tepung sebanyak $1 \mathrm{~g}$ dicampur dengan $10 \mathrm{~mL}$ aquades di dalam tabung reaksi kemudian dilakukan pengocokan selama 1 menit dan didiamkan selama 30 menit pada suhu ruang $24^{\circ} \mathrm{C}$. Proses selanjutnya yaitu disentrifugasi dengan kecepatan 3500 rpm selama 30 menit. Air yang tidak terserap dibuang dan air yang terserap merupakan nilai daya serap air. Nilai a diperoleh dari volume $10 \mathrm{~mL}$ aquades dan tabung reaksi, nilai $\mathrm{c}$ merupakan berat tepung sebanyak $1 \mathrm{~g}$ dan untuk nilai d adalah berat akhir dari tabung reaksi, tepung dan air. Rumus perhitungan DSA:

$$
\operatorname{DSA}(\mathrm{mL} / \mathrm{g})=(\mathrm{d}-\mathrm{c}-\mathrm{a}) / \mathrm{c}
$$

Keterangan:

$\mathrm{a}=$ berat tabung reaksi dan air $(\mathrm{g})$

$\mathrm{c}=$ berat tepung $(\mathrm{g})$

$\mathrm{d}=$ berat akhir tabung reaksi, tepung dan air $(\mathrm{g})$

Analisis Warna (Hunter, 1958)

Pengukuran menggunakan metode hunter dengan penilaian terdiri atas 3 parameter warna y aitu L, a, dan b. Dengan cara melakukan penembakan pada bubuk susu kedelai sebanyak 5 titik sehingga diperoleh nilai $\mathrm{dL}$, da, dan $\mathrm{db}$. Nilai standar dari Lt, at dan bt diperoleh dari penembakan awal pada kertas putih. Kemudian dilakukan perhitungan untuk mengetahui nilai $\mathrm{L}$, $\mathrm{a}$, dan $\mathrm{b}$ dengan persamaan seperti berikut:

$$
\begin{aligned}
& \mathrm{L}=\mathrm{dL}+\mathrm{Lt} \\
& \mathrm{a}=\mathrm{da}+\mathrm{at} \\
& \mathrm{b}=\mathrm{db}+\mathrm{bt}
\end{aligned}
$$

Keterangan:

$\mathrm{L}=$ tingkat kecerahan tepung

$\mathrm{a}=$ nilai kemerahan

$\mathrm{b}=$ nilai kekuningan

\section{Kadar Protein (AOAC 1995)}

Prinsip analisis kadar protein dan total nitrogen adalah proses pembebasan nitrogen dari protein dalam bahan menggunakan asam sulfat dengan pemanasan. Penentuan total nitrogen dan kadar protein menggunakan metode mikro kjeldahl.

$\%$ Protein $=\% \mathrm{~N} \times 6,25$

Keterangan:

$14,007=$ berat atom Nitrogen $(\mathrm{N})$

$6,25=$ faktor konversi protein-nitrogen

Kadar Lemak (AOAC 1995)

Metode yang digunakan dalam analisis lemak adalah metode ekstraksi soxhlet. Kadar lemak ditentukan sebagai berikut:

Kadar lemak $(\%)=\frac{\text { berat lemak }(\mathrm{g})}{\text { berat sampel }(\mathrm{g})} \times 100 \%$ 


\section{Analisis Data}

Data yang diperoleh dari variasi komposisi dekstrin dan Tween 80 merupakan hasil rata-rata dari tiga ulangan, setelah itu ditentukan sampel yang paling cepat kering dan selanjutnya dilakukan tahap optimasi suhu. Data dari variasi suhu pengeringan dianalisis menggunakan ANOVA dengan taraf nyata $\boldsymbol{\alpha}=0,05$ dan uji lanjut Duncan.

\section{HASIL DAN PEMBAHASAN}

\section{Pembuatan Bubuk Susu Kedelai Instan} Variasi Komposisi Dekstrin dan Tween 80

Kadar air awal dengan perlakuan variasi komposisi dekstrin dan Tween 80 ditunjukkan pada Tabel 1. Hasil menunjukkan bahwa penambahan dekstrin dan Tween 80 dapat menurunkan kadar air susu kedelai sebelum pengeringan.

Tabel 1. Kadar air awal dengan perlakuan variasi komposisi dekstrin dan Tween 80

\begin{tabular}{cc}
\hline Perlakuan & Kadar Air Awal $(\% \mathrm{bb})$ \\
\hline Non foam & $93,65 \pm 0,01 \mathrm{e}$ \\
D1T1 & $88,97 \pm 0,50 \mathrm{~d}$ \\
D1T2 & $88,81 \pm 0,44 \mathrm{c}$ \\
D2T1 & $85,75 \pm 0,35 \mathrm{~b}$ \\
D2T2 & $84,62 \pm 0,77 \mathrm{a}$ \\
\hline
\end{tabular}

*Notasi yang berbeda menunjukkan berbeda nyata pada taraf $5 \%$

Keterangan: D1T1 (5\% dekstrin 0,5\% Tween 80), D1T2 (5\% dekstrin 1\% Tween 80), D2T1 (10\% dekstrin 0,5\% Tween 80$)$, D2T2 (10\% dekstrin $1 \%$ Tween 80 )

Hasil analisis ragam menunjukkan bahwa konsentrasi dekstrin dan Tween 80 yang digunakan berpengaruh nyata terhadap kadar air awal susu kedelai. Perlakuan penambahan konsentrasi dekstrin $10 \%$ dan Tween 80 sebesar $1 \%$ memiliki hasil kadar air yang terendah yaitu $84,62 \%$. Konsentrasi dekstrin yang tinggi dapat menyerap lebih banyak kandungan air dalam bahan cair karena dekstrin bersifat higroskopis (Siska dan
Wahono, 2014). Semakin tinggi konsentrasi Tween 80 dapat memperbanyak terbentuknya busa. Busa yang terbentuk memudahkan penyerapan air saat pengocokan dan pencampuran sebelum dikeringkan (Kumalaningsih, 2006).

Kurva laju pengurangan air bahan diperoleh dengan mengukur massa air dalam bahan atau massa bahan setiap saat terhadap waktu (Treybal, 1981). Kurva massa air pada setiap variasi komposisi dekstrin dan Tween 80 disajikan pada Gambar 1.

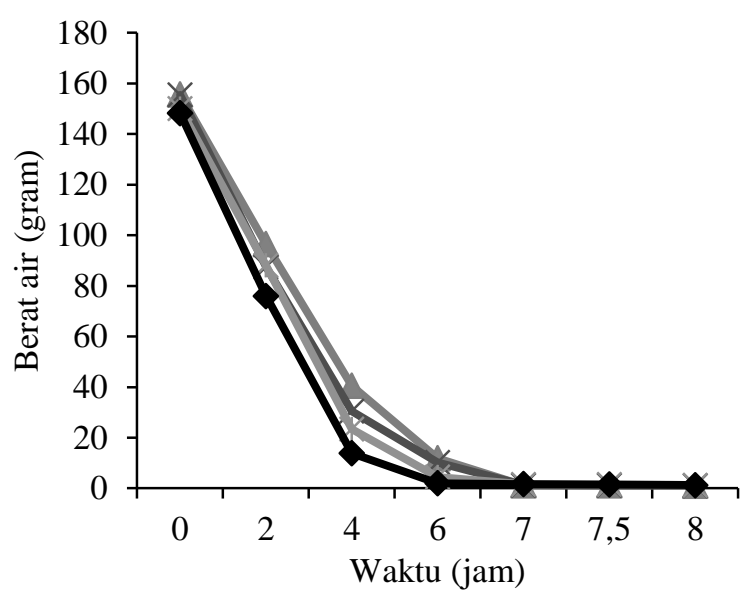

Gambar 1. Kurva massa air (gram) terhadap waktu (jam) pada setiap variasi komposisi dekstrin dan Tween 80 yaitu 5\% dekstrin $0,5 \%$ Tween 80 (D1T1, - ); $5 \%$ dekstrin $1 \%$ Tween 80 , $10 \%$ dekstrin $0,5 \%$ Tween 80 (D1T2, $\leftarrow$ ), (D2T1, 壮), $1 \%$ dekstrin $1 \%$ Tween 80 (D2T2, -

Pada awal pengeringan (0-4 jam) terjadi penurunan massa bahan yang cukup besar, dimana hal ini menunjukkan jumlah air yang berhasil diuapkan selama waktu pengeringan tersebut juga besar (Gambar 1). Seiring dengan bertambahnya waktu, hingga mencapai waktu tertentu, massa bahan tidak lagi mengalami perubahan. Suatu proses pengeringan dikatakan telah selesai jika massa bahan tidak lagi mengalami perubahan, dikarenakan pada kondisi tersebut air dalam bahan sudah 
tidak dapat diuapkan lagi (Pratiwi dan Suharto, 2015).

Variasi komposisi konsentrasi dekstrin dan Tween 80 (sampel D1T1, D1T2, D2T1, D2T2) tidak memiliki perbedaan signifikan terhadap laju pengeringan. Namun untuk mencapai kadar air standar minimal susu bubuk $(<5 \%)$, sampel D2T2 dengan komposisi dekstrin $10 \%$ dan Tween 80 sebesar $1 \%$ memberikan waktu pengeringan 30 menit lebih cepat dibanding ketiga sampel lainnya. Kemudian, sampel D2T2 ini yang akan digunakan untuk penelitian selanjutnya dengan memvariasi suhu pengeringan dan hasilnya akan dibandingkan dengan standar SNI susu bubuk (SNI 01-2970-2006).

\section{Variasi Suhu Pengeringan}

Pada penelitian ini bahan dikeringkan dengan variasi suhu $50^{\circ} \mathrm{C}$, $60^{\circ} \mathrm{C}$ dan $70^{\circ} \mathrm{C}$ dengan komposisi sampel yang sama, yaitu dekstrin $10 \%$ dan Tween 80 sebanyak $1 \%$. Nilai rata-rata kadar air sebelum pengeringan dan sesudah pengeringan dan juga lama proses pengeringan disajikan pada Tabel 2.

Tabel 2. Kadar air dan lama pengeringan pada perlakuan suhu yang berbeda

\begin{tabular}{cccc}
\hline $\begin{array}{l}\text { Perlakuan } \\
\text { suhu }\end{array}$ & $\begin{array}{c}\text { Kadar } \\
\text { air awal } \\
(\% \text { bb })\end{array}$ & $\begin{array}{c}\text { Kadar air } \\
\text { akhir }(\% \\
\text { bb })\end{array}$ & $\begin{array}{c}\text { Lama } \\
\text { pengeringan } \\
\text { (jam) }\end{array}$ \\
\hline $50^{\circ} \mathrm{C}$ & 84,62 & 5,15 & $12-16$ \\
$60^{\circ} \mathrm{C}$ & 84,62 & 4,46 & $8-10$ \\
$70^{\circ} \mathrm{C}$ & 84,62 & 3,05 & $6-8$ \\
\hline
\end{tabular}

Pengeringan bubuk susu kedelai metode foam-mat drying pada suhu yang berbeda akan memberikan waktu yang berbeda pula (Tabel 2). Semakin tinggi suhu yang digunakan pada proses pengeringan (suhu $70^{\circ} \mathrm{C}$ ) memberikan waktu tercepat yaitu 6-8 jam. Pengeringan suhu $50^{\circ} \mathrm{C}$ memberikan waktu terlama yaitu 12-16 jam. Dari penelitian yang dilakukan Kania et al.
(2015), pengeringan foam-mat drying minuman instan kecambah kacang komak pada suhu pengeringan oven $50^{\circ} \mathrm{C}$ membutuhkan waktu selama 17 jam. Kemudian, penelitian Pradana et al. (2014) menunjukkan waktu yang dibutuhkan untuk pengeringan bubuk susu kacang hijau dengan tunnel drying selama 10 jam pada suhu $60^{\circ} \mathrm{C}$. Selanjutnya, produk bubuk instan susu kedelai yang diperoleh pada berbagai variasi suhu pengeringan dilakukan pengujian karakteristik fisik maupun kimia.

\section{Karakteristik Bubuk Susu Kedelai Instan}

Karakteristik mutu bubuk susu kedelai instan pada penelitian ini berupa nilai rendemen, daya serap air, warna, kadar air, kadar protein dan kadar lemak. Berdasarkan SNI 01-2970-2006, karakteristik produk bubuk susu kedelai yang dijadikan acuan adalah nilai kadar air, protein dan lemak. Karakteristik mutu bubuk susu kedelai instan disajikan pada Tabel 3.

Kadar Air

Berdasarkan standar yang ditetapkan oleh SNI 01-2970-2006, nilai kadar air untuk susu bubuk maksimal 5\%. Kadar air produk bubuk susu kedelai instan pada suhu $60^{\circ} \mathrm{C}$ dan $70^{\circ} \mathrm{C}$ yaitu $4,46 \%$ dan $3,05 \%$ (Tabel 3) sudah sesuai dengan syarat mutu susu bubuk SNI 01-29702006. Analisis ragam menunjukkan bahwa perbedaan suhu berpengaruh nyata terhadap kadar air produk bubuk yang dihasilkan. Hasil uji lanjut Duncan 5\% menunjukkan terjadi perbedaan kadar air bubuk susu kedelai instan pada suhu pengeringan yang berbeda.

Suhu pengeringan yang semakin tinggi menghasilkan produk dengan kadar air yang lebih rendah. Hal ini sejalan dengan hasil penelitian Pratiwi dan Suharto (2015), menyatakan bahwa suhu pengeringan berpengaruh terhadap kadar air disebabkan karena dengan semakin 
tingginya suhu maka semakin banyak molekul air yang menguap dari umbi talas yang dikeringkan sehingga kadar air yang diperoleh semakin rendah.

Tabel 3. Karakteristik mutu bubuk susu kedelai instan pada variasi suhu pengeringan

\begin{tabular}{|c|c|c|c|}
\hline Parameter & & $\begin{array}{c}\text { Hasil } \\
\text { Penelitian } \\
\end{array}$ & SNI \\
\hline \multirow[t]{3}{*}{ Kadar Air } & $50^{\circ} \mathrm{C}$ & $5.15 \pm 0.28 c$ & \\
\hline & $60^{\circ} \mathrm{C}$ & $4.47 \pm 0.01 b$ & maks. $5 \%$ \\
\hline & $70^{\circ} \mathrm{C}$ & $3.31 \pm 0.27 \mathrm{a}$ & \\
\hline \multicolumn{4}{|l|}{ Kadar } \\
\hline \multirow[t]{3}{*}{ Protein } & $50^{\circ} \mathrm{C}$ & $14.66 \pm 0.06 b$ & \\
\hline & $60^{\circ} \mathrm{C}$ & $23.08 \pm 0.16 c$ & $\min .23 \%$ \\
\hline & $70^{\circ} \mathrm{C}$ & $13.01 \pm 0.30 \mathrm{a}$ & \\
\hline \multicolumn{4}{|l|}{ Kadar } \\
\hline \multirow[t]{3}{*}{ Lemak } & $50^{\circ} \mathrm{C}$ & $11.36 \pm 0.44 c$ & $1,5 \%<x<26 \%$ \\
\hline & $60^{\circ} \mathrm{C}$ & $7.89 \pm 0.08 \mathrm{a}$ & \\
\hline & $70^{\circ} \mathrm{C}$ & $9.67 \pm 0.07 b$ & \\
\hline \multirow[t]{3}{*}{ Rendemen } & $50^{\circ} \mathrm{C}$ & $16,10 \pm 0,02 \mathrm{c}$ & \\
\hline & $60^{\circ} \mathrm{C}$ & $16,03 \pm 0,01 b$ & - \\
\hline & $70^{\circ} \mathrm{C}$ & $15,69 \pm 0,03 a$ & \\
\hline \multirow[t]{3}{*}{ DSA } & $50^{\circ} \mathrm{C}$ & $1.46 \pm 0.05 a$ & \\
\hline & $60^{\circ} \mathrm{C}$ & $1.68 \pm 0.04 c$ & - \\
\hline & $70^{\circ} \mathrm{C}$ & $1.58 \pm 0.03 b$ & \\
\hline Warna & & & - \\
\hline \multirow[t]{3}{*}{$\mathrm{L}$} & $50^{\circ} \mathrm{C}$ & $83.5 \pm 0.2 b$ & \\
\hline & $60^{\circ} \mathrm{C}$ & $84.2 \pm 0.1 c$ & \\
\hline & $70^{\circ} \mathrm{C}$ & $81.8 \pm 0.1 \mathrm{a}$ & \\
\hline \multirow[t]{3}{*}{ A } & $50^{\circ} \mathrm{C}$ & $2.1 \pm 0.1 b$ & \\
\hline & $60^{\circ} \mathrm{C}$ & $1.3 \pm 0.0 \mathrm{a}$ & \\
\hline & $70^{\circ} \mathrm{C}$ & $2.5 \pm 0.1 c$ & \\
\hline \multirow[t]{3}{*}{ B } & $50^{\circ} \mathrm{C}$ & $21.5 \pm 0.1 \mathrm{a}$ & \\
\hline & $60^{\circ} \mathrm{C}$ & $24.2 \pm 0.6 b$ & \\
\hline & $70^{\circ} \mathrm{C}$ & $21.8 \pm 0.3 \mathrm{a}$ & \\
\hline
\end{tabular}

\section{Kadar Protein}

Hasil analisis sidik ragam suhu pengeringan memiliki pengaruh yang berbeda nyata terhadap kadar protein bubuk susu kedelai instan yang dihasilkan (Tabel 3). Kadar protein tertinggi diperoleh pada pengeringan suhu $60^{\circ} \mathrm{C}$ yaitu sebesar 23,08\% dan memenuhi syarat mutu susu bubuk SNI 01-29702006. Nilai kadar protein pada suhu $50^{\circ} \mathrm{C}$ dan $70^{\circ} \mathrm{C}$ tidak memenuhi standar mutu susu bubuk yaitu dibawah $23 \%$. Diduga hal ini disebabkan kandungan protein dalam bahan terdenaturasi akibat suhu pengeringan yang semakin tinggi yaitu suhu $70^{\circ} \mathrm{C}$. Pada suhu $50^{\circ} \mathrm{C}$ pengeringan berlangsung lebih lama yang dapat menyebabkan penguapan air dalam bahan sangat cepat sehingga air dalam bahan berkurang dan mempengaruhi protein dalam bahan.

Sesuai dengan pendapat Yuniarti et al. (2013) dalam Lisa et al. (2015), bahwa pemanasan dengan suhu yang tinggi akan menyebabkan protein terdenaturasi. Pemanasan dapat merusak asam amino dimana ketahanan protein oleh panas sangat terkait dengan asam amino penyusun protein tersebut, sehingga hal ini yang menyebabkan kadar protein menurun dengan semakin meningkatnya suhu pemanasan.

Nilai kadar protein dari hasil penelitian ini masih tinggi jika dibandingkan dengan penelitian lain. Pramitasari (2010) menyatakan bahwa kadar protein bubuk susu kedelai instan dengan metode spray drying yaitu 1113\%, sedangkan Pradana et al. (2014) menunjukkan kadar protein bubuk susu kacang hijau dengan metode foam-mat drying yaitu 7,8\%. Selain itu, Khrisnawaty dan Moeljaningsih (2011) menyatakan kadar protein bubuk susu campuran jagung manis dan kacang hijau dengan metode foam-mat drying sebesar $3,75 \%$.

\section{Kadar Lemak}

Susu kedelai merupakan minuman yang bergizi tinggi, terutama karena kandungan proteinnya. Selain itu, susu kedelai juga mengandung lemak. Lemak adalah komponen makanan yang tidak larut air (Winarno, 2007). Hasil analisis kadar lemak bubuk susu kedelai instan (Tabel 3) yaitu 7,92\%-11,36\%, dimana 
dari ketiga variasi suhu pengeringan telah memenuhi ketentuan yang ditetapkan dalam SNI 01-2970-2006 untuk bubuk susu yaitu berkisar 1,5-26\%.

Analisis sidik ragam menunjukkan bahwa perbedaan suhu berbeda nyata terhadap kandungan lemak bubuk susu kedelai. Suhu pengeringan $50^{\circ} \mathrm{C}$ menghasilkan kadar lemak yang tinggi dibandingkan suhu $60^{\circ} \mathrm{C}$ dan $70^{\circ} \mathrm{C}$. Hal ini karena pada suhu $50^{\circ} \mathrm{C}$ membutuhkan waktu pengeringan yang lebih lama untuk menurunkan kadar air, menyebabkan peningkatan kadar lemak berbanding terbalik dengan nilai kadar air yang semakin menunjukkan penurunan seiring dengan semakin tinggi suhu yang digunakan selama proses pengeringan.

\section{Rendemen}

Rendemen bubuk susu kedelai instan dihitung berdasarkan jumlah fitrat susu kedelai sebelum pengeringan. Nilai rendemen pada variasi suhu pengeringan (Tabel 3) adalah 15,69\% sampai dengan $16,10 \%$. Hasil analisis sidik ragam menunjukkan bahwa perbedaan suhu pengeringan memiliki pengaruh yang nyata terhadap nilai rendemen bubuk susu kedelai yang dihasilkan. Rendemen bubuk susu kedelai instan pada pengeringan suhu $50^{\circ} \mathrm{C}$ dan $60^{\circ} \mathrm{C}$ yaitu $16,03 \%$ dan $16,10 \%$ dan mulai menurun pada suhu $70^{\circ} \mathrm{C}$ yaitu 15,69\%. Hal ini sesuai dengan pendapat Winarno (1993), yang menyatakan bahwa proses pengeringan menyebabkan kandungan air selama proses pengolahan berkurang sehingga menyebabkan penurunan rendemen. Berdasarkan penelitian Wijana et al. (2011) nilai rendemen suatu produk akan semakin menurun jika suhu pengeringan semakin tinggi. Hal ini juga didukung dengan

\section{Daya Serap Air}

Nilai daya serap air bubuk susu kedelai instan pada variasi suhu pengeringan (Tabel 3) berkisar dari 1,46$1,68 \mathrm{~mL} / \mathrm{g}$. Analisis sidik ragam menunjukkan suhu pengeringan memberikan pengaruh yang nyata terhadap daya serap air dari bubuk susu kedelai. Selain suhu pengeringan, Endryani (2012) menyatakan bahwa kemampuan menyerap air pada produk berhubungan dengan kemampuan mengikat air bahan pengikat yang digunakan yaitu dekstrin dan Tween 80. Nilai daya serap air tertinggi pada suhu $60^{\circ} \mathrm{C}$ yaitu sebesar $1,68 \mathrm{~mL} / \mathrm{g}$, menurut Purwanto et al. (2013) semakin tinggi daya serap air pada tepung maka kualitas tepung tersebut semakin baik karena tepung mampu menyerap air dengan baik seperti olahan bubur yang memerlukan penyerapan air yang baik. Penelitian Kumalaningsih (2006) menunjukkan nilai daya serap air minuman fungsional instan campuran sari buah terung pirus dan markisa berkisar antara 0,13-0,25 mL/g, sedangkan Kania et al. (2015) menyatakan bahwa nilai daya serap minuman instan kecambah komak antara 2,65-2,77 mL/g.

\section{Warna}

Nilai L (Tingkat Kecerahan)

Parameter L menunjukkan tingkat kecerahan yaitu antara warna putih (100) sampai dengan hitam (0). Penambahan bahan pengisi berupa dekstrin pada metode foam-mat dying menyebabkan warna produk makin cerah karena warna dekstrin adalah putih (Darniadi, 2011). Tabel 3 menunjukkan bahwa hasil analisis sidik ragam menunjukkan bahwa suhu pengeringan memiliki pengaruh yang nyata terhadap nilai $L$, yaitu berkisar antara 81,9-84,2. Nilai L tertinggi yaitu pada suhu pengeringan $60^{\circ} \mathrm{C}$ yang menunjukkan warna bubuk susu kedelai adalah kuning cerah. Sedangkan pada suhu lebih tinggi (suhu $70^{\circ} \mathrm{C}$ ) menghasilkan nilai $\mathrm{L}$ yang lebih rendah yaitu 81,9. Warna awal susu kedelai adalah kekuningan, sehingga dengan suhu pengeringan yang lebih tinggi akan menghasilkan produk yang berwarna kuning kecoklatan. Menurut Labuza (1982), suhu memiliki pengaruh yang 
besar terhadap pencoklatan non-enzimatis, dimana setiap kenaikan suhu sebesar $10^{\circ} \mathrm{C}$ kecepatan proses pencoklatan meningkat 4-8 kali.

\section{Nilai a (Tingkat Kemerahan)}

Tingkat kemerahan bernilai (-) maka tingkat warna mendekati warna hijau sedangkan untuk nilai (+) mendekati warna merah. Berdasarkan pengukuran nilai tingkat kemerahan bubuk susu kedelai instan pada variasi suhu pengeringan berkisar 1,3-2,2. Hasil analisis sidik ragam, variasi suhu pengeringan memberikan pengaruh yang nyata terhadap nilai tingkat kemerahan produk. Nilai tingkat kemerahan tertinggi pada produk dengan suhu pengeringan $70^{\circ} \mathrm{C}$. Hal ini menunjukkan bahwa semakin tinggi suhu pengeringan semakin besar nilai a yang artinya warna produk mendekati warna merah.

\section{Nilai b (Tingkat Kekuningan)}

Nilai b menyatakan tingkat birukuning, semakin mendekati (+) maka warna cenderung berwarna kuning, sedangkan (-) maka warna cenderung biru. Nilai tingkat kekuningan bubuk susu kedelai instan berkisar antara 21,5-24 (Tabel 3). Analisis sidik ragam menunjukkan bahwa suhu memiliki pengaruh yang nyata terhadap nilai tingkat kekuningan. Nilai tingkat kekuningan tertinggi terdapat pada produk dengan suhu pengeringan $60^{\circ} \mathrm{C}$, sedangkan pada suhu $50^{\circ} \mathrm{C}$ dan $70^{\circ} \mathrm{C}$ tidak berbeda nyata. Hal ini menunjukkan produk yang dihasilkan dengan pengeringan suhu $60^{\circ} \mathrm{C}$ memiliki warna yang mendekati warna susu kedelai murni yaitu kekuningan.

\section{KESIMPULAN}

Konsentrasi dekstrin $10 \%$ dan Tween 80 sebesar 1\% sebagai bahan pengisi pada pembuatan bubuk susu kedelai instan dengan metode foam-mat drying memberikan waktu pengeringan paling cepat yaitu 8 jam dengan kadar air terendah yaitu 4,46\%. Kondisi operasi terbaik dan memenuhi SNI susu bubuk dengan metode foam-mat drying adalah pada suhu pengeringan $60^{\circ} \mathrm{C}$ yaitu kadar air $4,47 \%$, kadar protein $17,34 \%$ dan kadar lemak $7,89 \%$. Nilai rendemen tertinggi pada suhu pengeringan $60^{\circ} \mathrm{C}$ yaitu $16,10 \%$, tingkat kecerahan (L) sebesar 84,2; tingkat kemerahan (a) sebesar 1,3; tingkat kekuningan (b) sebesar 24, serta daya serap air (DSA) sebesar $1,68 \mathrm{~mL} / \mathrm{g}$.

\section{UCAPAN TERIMA KASIH}

Ucapan terimakasih ditujukan kepada Lembaga Penelitian dan Pengabdian Masyarakat Universitas Jember yang telah mendukung secara finansial melalui Program Penelitian Pembinaan Universitas Jember Tahun Anggaran 2016.

\section{DAFTAR PUSTAKA}

AOAC. 1995. Official Methods of Analysis of The Association of Analytical Chemists. Washington D.C.

Badan Standarisasi Nasional. 2006. Standar Nasional Indonesia (SNI). SNI-012970-2006. Susu Bubuk. Dewan Standarisasi Indonesia. Jakarta.

Darniadi,S., Sofyan, I., Arief, D.Z. 2011. Karakteristik fisiko-kimia dan organoleptik bubuk minuman instan sari jambu biji merah (Psidium guajava L.) yang dibuat dengan metode foam mat drying.(http://widyariset.pusbindiklat.lipi. go.id/index.php/widyariset/article/viewFil e/432/35) [Diakses pada 12 Oktober 2016].

Endriyani, C.E. 2012. Kajian Karakteristik Fisiko Kimia dan Sensori Mikroenkapsulan Ekstrak Tempe Bosok Terstandar Sebagai Food Seasoning dengan Variasi Rasio Enkapsulan Gum Arab dan Maltodekstrin. Skripsi. Program Studi Ilmu dan Teknologi Pangan. Fakultas Pertanian, Universitas Sebelas Maret.Surakarta.(https://eprints.uns.ac.id/ 7635/1/143841308201008361.pdf) [Diakses pada 13 Oktober 2016]. 
Hui, Y.H. 1992. Encyclopedia of Food Science and Technology. John Wiley and Sons Inc. New York.

Hunter, R. S. 1958. Photoelectric color difference meter. Journal of the Optical Society of America, 48 (597): 985-995.

Kania, W., Andriani, M.A., dan Siswanti, M. 2015. Pengaruh variasi rasio bahan pengikat terhadap karakteristik fisik dan kimia granul minuman fungsional instan kecambah kacang komak (Lablab purpureus (L) Sweet). Jurnal Teknosains Pangan, 4 (3): 16-29.

Khotimah, K. 2006. Pembuatan susu bubuk dengan foam mat drying: Kajian pengaruh bahan penstabil terhadap kualitas susu bubuk. Jurnal Protein, 13 (1): 44-51.

Khrisnawaty, S., dan Moeljaningsih. 2011. Pembuatan susu bubuk dari campuran susu jagung manis dan susu kacang hijau. Berita Litbang Industri, IV (1): 47-55.

Kumalaningsih. 2006. Pembuatan bubuk instan campuran sari buah terung pirus (Cyphomandra betacea Cav. Sendtner) dan markisa (Fassflora edulis var Falvicarva) dengan metode foam-mat drying.(http://jambi.litbang.pertanian.go.i d/eng/images/PDF/Markisahterung\%20pirus.pdf). [Diakses pada 12 Oktober 2016].

Labuza, T.P. 1982. Shelf Life Dating of Foods. Food and Nutrition Press. Westport, Connecticut.

Lisa, Maya., Mustofa Lutfi, dan Bambang Susilo. 2015. Pengaruh suhu dan lama pengeringan terhadap mutu tepung jamur tiram putih (Plaerotus ostreatus). Jurnal Keteknikan Pertanian Tropis dan Biosistem, 3 (3): 270-279.

Pradana, S.W., Kumalaningsih, S., Dewi, I.A. 2014. Pembuatan bubuk susu kacang hijau (Phaseolus radiatus L.) instan menggunakan metode foam mat drying (Kajian konsentrasi maltodekstrin dan tween 80). (http://skripsitip.staff.ub.ac.id/files/2014/ 02/Jurnal-Suka-Wika Pradana.pdf) [Diakses pada 12 Oktober 2016].
Pramitasari, D. 2010. "Penambahan Ekstrak Jahe (Zingiber officinale rosc.) Dalam Pembuatan Susu Kedelai Bubuk Instan Dengan Metode Spray Drying: Komposisi Kimia, Sifat Sensori dan Aktivitas Antioksidan”. Skripsi. Program Studi Teknologi Hasil Pertanian, Fakultas Pertanian, Universitas Sebelas Maret.

Prasetyo, S dan Vincentius. 2005. Pengaruh Penambaan Tween 80, Dekstrin, dan Minyak Kelapa Pada Pembuatan Kopi Instan Menggunakan Metode Pengering Busa. Jurnal Teknik Kimia Indonesia, 4(3): 296-303.

Pratiwi, A.D., dan Suharto, I. 2015. Pengaruh Temperatur dan Tebal Lapisan Susu Kedelai pada Tray dalam Pengeringan Busa terhadap Kualitas Susu Kedelai Bubuk. Prosiding Seminar Nasional Teknik Kimia "Kejuangan”. Yogyakarta.

Purwanto, C.C., Ishartani, D., Rahardian, D. 2013. Kajian sifat fisik dan kimia tepung labu kuning (Cucurbita maxima) Dengan perlakuan blanching dan perendaman natrium metabisulfit $\left(\mathrm{Na}_{2} \mathrm{~S}_{2} \mathrm{O}_{5}\right)$. Jurnal Teknosains Pangan, 2 (2): 121-130.

Rajkumar, P., Kailappan, R., Viswanathan, R., Raghavan and Ratti, C. 2007. Foam mat drying of alphonso mango pulp. Drying Technology, 25: 357-365.

Traina, M.S. and Breene, W.M. 1994. Composition, functionality and some chemical and physical properties of eight commercial full-fat soy flour. J. Food Process Press, 8: 229-252.

Treybal, R.E. 1981. Mass-Transfer Operasions. 3th Edition. Mc Graw Hill, Inc. New YoRK.

Siska, Y.T., dan Wahono, H.S. 2014. Pengaruh lama pengeringan dan konsentrasi maltodekstrin terhadap karakteristik fisik kimia dan organoleptik minuman instan daun mengkudu (Morinda citrifolia.L). Jurnal Pangan dan Agroindustri, 3 (1): 41-52. 
Wijana, S., Sucipto, dan Sari, M. L. 2011. Pengaruh suhu dan waktu pengeringan terhadap aktivitas antioksidan pada bubuk kulit manggis (Garcinia mangostana L.). (http://skripsitipftp.staff.ub.ac.id/files/201 5/05/7.-JURNAL-Lia-Meika-Sari.pdf)

[Diakses pada 16 September 2016]

Winarno, F. G. 1993. Pangan Gizi, Teknologi dan Konsumen. Gramedia Pustaka Utama, Jakarta.

Winarno, F.G. 2007. Kimia Pangan dan Gizi. Gramedia Pustaka Utama, Jakarta.

Yuwono, S.S., dan Susanto, T. 2001. Pengujian Fisik Pangan. Jurusan Teknologi Hasil Pertanian, Fakultas Teknologi Pertanian, Universitas Brawijaya, Malang. 